\title{
MANAJEMEN PENDIDIKAN ISLAM
}

\author{
Barsihannor \\ Fakultas Studi Islam Universitas Islam Kalimantan Banjarmasin \\ e-mail: barsihanor2021@gmail.com
}

\begin{abstract}
ABSTRACK
This article examines thoughts of Prof. Dr. Mujamil Qomar, M.Ag. which expressly states that the success of Islamic education in the level of realityexpectations one of which is determined by the management of Islamic education that serves the task of advancing the implementation, implementation or application of Islamic education institutionally. Among Qomar's thoughts on the management of Islamic education that is pithy and deserves an in-depth study is the nature of Islamic education management and its implications, philosophical objects and praxis as well as the dimensions of Islamic education management, the characteristics and characteristics of Islamic education management, the difference between Islamic education management and education management, as well as about the existence and constraints of Islamic education management. Thought Qomar can be explored clearly in three works, namely Manajemen Pendidikan Islam: Strategi Baru Pengelolaan Lembaga Pendidikan Islam (Management of Islamic Education: New Strategy Management of Islamic Education Institutions), Dimensions of Management of Islamic Education, and Strategy of Islamic Education, as well as other works that are not directly related to the discussion of Islamic education management.
\end{abstract}

\footnotetext{
ABSTRAK

Artikel ini mengkaji pemikiran Prof. Dr. Mujamil Qomar, M.Ag. yang secara tegas menyatakan bahwa keberhasilan pendidikan Islam dalam tataran realitasekspektasional salah satunya adalah ditentukan oleh manajemen pendidikan Islam yang berfungsi menjalankan tugas memajukan penyelenggaraan, pelaksanaan atau penerapan pendidikan Islam secara kelembagaan. Di antara pemikiran Qomar tentang manajemen pendidikan Islam yang bernas dan patut mendapatkan telaah
} 
mendalam adalah tentang hakikat manajemen pendidikan Islam dan impilkasinya, objek filosofis dan praksis serta dimensi dari manajemen pendidikan Islam, ciri dan karakteristik manajemen pendidikan Islam, perbedaan antara manajemen pendidikan Islam dan manajemen pendidikan, serta tentang eksistensi dan hambatan manajemen pendidikan Islam. Pemikiran Qomar tersebut dapat digali dengan jelas dalam tiga karyanya, yaitu Manajemen Pendidikan Islam: Strategi Baru Pengelolaan Lembaga Pendidikan Islam, Dimensi Manajemen Pendidikan Islam, dan Strategi Pendidikan Islam, serta karya-karya lainnya yang tidak berkaitan langsung dengan pembahasan manajemen pendidikan Islam.

\section{Keyword: thought, management, Islamic education}

\section{PENDAHULUAN}

Pendidikan Islam walaupun secara teoritis-konseptul dan secara realitas historis masa lalunya telah dan pernah mengalami kejayaan dan kamajuan yang di akui, namun dalam tataran realitas empiris kontemporer dan ekspektasional kekiniannya mengalami kemerosotan dan kemunduran sebagaimana yang dinyatakan oleh banyak pakar pendidikan Islam itu sendiri.

Kesimpulan dan realitas tersebut dalam penelusuran Kemas Badaruddin (2009: 1-3), Jalaluddin dan Usman Said (1999: 159), serta Mâjid "Irsân Al-Kîlânî (1987: 65), setidaknya pernah dikemukakan oleh banyak tokoh pendidikan Islam, seperti Syed Muhammad Al-Naquib Al-Attas, Ismaeil Raji Al-Faruqi, Hasan Langgulung, Khursid Ahmad, Ziauddin Sardar, Hamid Hasan AlBilgrami, Syed Sajjad Husein, Syed Ali Ashraf. Bahkan kemunduran pendidikan Islam ini kemudian dinyatakan pula sebagai penyebab utama kemunduran umat Islam, yaitu lemahnya sistem pendidikan yang berlangsung selama ini.

Selain karena faktor internal tersebut, krisis pendidikan juga diperparah oleh masifnya invasi pemikiran (ghazw fikrî) terhadap dunia pendidikan Islam, yang bahkan menjadi fokus utama para musuh (outsider) kaum Muslimin. Menurut Manshûr "Abd Al-“Azîz Al-Khirrîjî (1420 H.: 153) dan Hassân Muhammad Hassân (1414 H.), krisis pendidikan Islam, spesifiknya melalui saranaprasarananya yang dihegemoni oleh cengkeraman para pelaku ghazw fikrî mampu mewariskan 
krisis atau kekalahan psikologis (hazîmah nafsiyyah) yangberkepanjangan dan kemudian menggerogoti berbagai aspek kependidikan lainnya.Krisis atau kemunduran pendidikan Islam dalam tataran

internasional tersebut di atas, juga dialami oleh pendidikan Islam di Indonesia bahkan pendidikan di Indonesia secara umum, karena banyak pihak yang mengasumsikan bahwa krisis pendidikan Islam justru terjadi lebih parah seperti testimoni yang banyak disuarakan oleh para pakar dan pemerhati pendidikan dengan ungkapan yang cukup provokatif, "mengalami krisis identitas karena lonceng kematiannya telah berdentang", "dalam kondisi hidup enggan mati tak mau”, "jiplakan”, "surutnya intelektualisme Islam sebagai akibat kemandulan pendidikan Islam" (Mahmud Arif, 2008: 70), dan ungkapan-ungkapan bernada satir dan pesimistis lainnya.

Secara khusus pendidikan Islam di Indonesia juga menghadapi berbagai persoalan dan kesenjangan dalam berbagai aspek yang lebih kompleks, yaitu berupa persoalan dikotomi pendidikan, kurikulum, tujuan, sumber daya, dan manajemen pendidikan Islam. Upaya perbaikannya pun belum dilakukan secara mendasar, sehingga terkesan seadanya saja. Usaha pembaruannya secara mendasar seringkali dihambat oleh berbagai masalah, mulai dari persoalan dana sampai tenaga ahli, sehingga "pendidikan Islam dewasa ini terlihat orientasinya yang semakin kurang jelas" (Hujair AH. Sanaky, 2003: 9).

Untuk menghindari realitas negatif dari pendidikan Islam secara empirik tersebut, juga untuk pengembangan dan kontinuitas keberlangsungannya, diperlukan pula upaya perbaikan, revitalisasi, reformasi, reformulasi, rekonstruksi, dan pembaruan secara berkesinambungan.

Namun para ahli pendidikan Islam juga menyatakan bahwa pendidikansendiri yang mampu mengatasi kemunduran umat tersebut dan untuk kemudian memajukannya, yaitu memajukan keadaan umat Islam melalui kemajuan pendidikan Islamnya.

Di antara upaya tersebut misalnya seperti yang pernah dikemukakan oleh Mastuhu (2003: 66) adalah dengan menggagas "paradigma pendidikan bermutu", yaitu pendidikan yang memiliki 
kejelasan visi, misi, orientasi, tujuan, dan strategi mencapai cita-cita pendidikan yang diselenggarakan. Hal ini dengan mempertimbangkan faktor lainnya, termasuk langkah inovatif dan strategis yang harus dilakukan oleh pendidikan Islam dalam menghadapi globalisasi dengan segala tantangan dan problematikanya (Abuddin Nata, 292-299).

Sedangkan menurut Prof. Dr. Mujamil Qomar, M.Ag. yang kemudiandinyatakan sebagai Mujamil Qomar(2012: 274), agar Islam maju, maka pendidikan adalah aspek yang paling utama untuk mendapatkan perbaikan. Sebab pendidikan sebagai variabel penentu atau variabel bebas (independent variable), sedangkan aspek-aspek lainnya merupakan variabel akibat atau variabel terikat (dependent variable). Melalui argumentasi kausalitas inilah, pendidikan memiliki kekuatan penentu, penyebab atau pengarah terhadap aspek-aspek lainnya.

Kemudian agar pendidikan Islam maju, bermutu atau berkualitas secara realitas sesuai dengan ekspektasi yang ideal, menurut Qomar (2013: 2) setidaknya harus ditemukan tiga kunci pembukanya dan dipakai sebagai resep untuk meraih kemajuannya. Yaitu (1) epistemologi pendidikan Islam; (2)

manajemen pendidikan Islam; dan (3) kesadaran pendidikan.

Secara gamblang Qomar (2013: 3-7) kemudian mendeskripsikan dan mengungkapkan secara analitis ketiga kunci kemajuan pendidikan Islam tersebut.

Kunci pertama yaitu epistemologi pendidikan Islam, menurut Qomar berkaitan dengan pendidikan Islam yang berbentuk ide-ide, gagasan-gagasan, pemikiran-pemikiran, wawasanwawasan, konsep-konsep, dan teori-teori. Epistemologi pendidikan Islam ini berfungsi menggali, menemukan, dan mengembangkan pengetahuan pendidikan Islam.

Untuk menjabarkan kunci pertama ini dalam bentuk "petunjuk pelaksanaan" atau "petunjuk teknis", Qomar telah menulis buku yang berjudul Epistemologi Pendidikan Islam dari Metode Rasional hingga Metode Kritik. 
Menurut Qomar, pembahasan epistemologi pendidikan Islam lebih diarahkan pada metode atau pendekatan yang dapat dipakai untuk membangun ilmu pendidikan Islam, daripada komponenkomponen lainnya, karena metode tersebut paling dekat dengan upaya untuk mengembangkan pendidikan Islam, baik secara konseptual maupun aplikatif (2006: 249).

Kunci kedua yaitu manajemen pendidikan Islam, berfungsi untuk menjalankan tugas memajukan penyelenggaraan, pelaksanaan atau penerapan pendidikan Islam secara kelembagaan.

Untuk menjabarkan kunci kedua ini, Qomar telah menulis buku yang berjudul Manajemen Pendidikan Islam: Strategi Baru Pengelolaan Lembaga Pendidikan Islam dan juga bukuDimensi Manajemen Pendidikan Islam.

Sedangkan kunci ketiga yaitu kesadaran pendidikan, berfungsi untuk memajukan perilaku umat Islam dalam mengikuti proses pendidikan Islam dan meraih hasilnya.

Untuk menjabarkan kunci ketiga ini, Qomar telah menulis buku yang berjudul Kesadaran Pendidikan: Sebuah Penentu Keberhasilan Pendidikan (2012).

Ketiga kunci tersebut oleh Qomar bahkan dinyatakan sebagai strategi atau tiga langkah mendasar untuk memajukan pendidikan Islam dalam menghadapi era globalisasi yang seharusnya mendapat perhatian para pemikir, penentu kebijakan, praktisi, dan manajer atau pemimpin lembaga pendidikan Islam (2014: 141).

Dari ketiga kunci kemajuan dan keberhasilan pendidikan Islam seperti yang ditawarkan oleh Qomar tersebut dapat disimpulkan bahwa manajemen pendidikan Islam termasuk hal yang harus mendapatkan atensi perhatian dan pembenahan yang bersifat kontinuitas.

Berdasarkan rasionalitas tersebut, artikel ini ditujukan untuk mengkaji pemikiran bernas Prof. Dr. Mujamil Qomar, M.Ag. tentang hal-hal sangat urgen dan khas dari manajemen pendidikan Islam yang belum banyak diungkap, yang terdapat karya-karyanya yang berhasil dilacak atau setidaknya yang telah diterbitkan secara luas. 


\section{TINJAUAN PUSTAKA}

Kajian dalam artikel ini difokuskan untuk menggali perspektif dan mengkaji pemikiran Prof. Dr. Mujamil Qomar, M.Ag. yang memiliki atensi besar dalam mendeskripsikan Manajemen Pendidikan Islam dan menganalisis pelbagai permasalahannya untuk kemudian dikemukakan solusi inovatifstrategik bagi pengembangan dan kemajuan pendidikan Islam secara general dan secara parsialistik yang berkaitan dengan manajemen pendidikannya.

Pemikiran Mujamil Qomar terekam pembahasannya dan dapat dielaborasi pemikirannya dengan jelas setidaknya seperti yang terdapat dalam tiga karyanya, yaitu (1) Manajemen Pendidikan Islam: Strategi Baru Pengelolaan Lembaga Pendidikan Islam; (2) Dimensi Manajemen Pendidikan Islam; dan (3) Strategi Pendidikan Islam.

Selain dari ketiga karyanyatersebut, dielaborasi pula beberapa karya lain dari Mujamil Qomar yang memiliki singgungan pembahasan dengan Manajemen Pendidikan Islam dan yang mendukung pemikirannya, antara lain bukunya yang berjudul Epistemologi Pendidikan Islam dari Metode Rasional hingga Metode Kritik, Kesadaran Pendidikan: Sebuah Penentu Keberhasilan Pendidikan, Menggagas Pendidikan Islam, dan karya-karya pendukung lainnya yang terkait, baik langsung maupun tidak langsung.

\section{METODE}

Manajemen pendidikan Islam terdiri dari tiga kata, yaitu term manajemen, pendidikan, dan Islam.

Manajemen secara bahasa berasal dari bahasa Inggris, yaitu management. Kata management berasal dari kata kerja to manage yang berarti mengurusi (Sulistyorini, 2009: 8).Atau dapat berarti mengurus, mengatur, mengemudikan, mengendalikan, menangani, mengelola, menyelenggarakan, menjalankan, melaksanakan, dan memimpin. Kata management berasal dari bahasa Latin, yaitu mano yang berarti tangan, menjadi manus berarti bekerja berkali-kali dengan menggunakan tangan, ditambah imbuhan agere yang berarti melakukan sesuatu, sehingga menjadi managiare 
yang berarti melakukan sesuatu berkali-kali dengan menggunakan tangan-tangan (Imam Machali dan Ara Hidayat, 2018: 1).

Menurut Muhammad Abdul Jawwad (2004: 118-119), dalam bahasa Arab manajemen secara etimologi diwakili oleh term nazhzhama-yunazhzhimu-tanzhîman yang berarti menata beberapa hal dan menggabungkan antara satu dengan yang lainnya, atau berarti menyusun dan menertibkan sesuatu. Maksudnya adalah aktifitas menertibkan, mengatur, dan berpikir yang dilakukan oleh seseorang, sehingga dia mampu menurutkan, menata, dan merapikan hal-hal yang ada di sekitarnya, mengetahui proritas-prioritasnya, serta menjadikan hidupnya selalu selaras dan serasi dengan yang lainnya.

Dalam Kamus Besar Bahasa Indonesia yang disusun oleh Pusat Bahasa Departemen Pendidikan Nasional (2012: 326), pendidikan dinyatakan sebagai "proses pengubahan sikap dan tata laku seseorang atau kelompok orang dalam usaha mendewasakan manusia melalui upaya pengajaran dan pelatihan; proses, cara, dan perbuatan mendidik".

menjelaskan hakekat pendidikan dan sekaligus tujuannya yang paling fundamental, yaitu proses pemanusiaan manusia, baik oleh pihak lain maupun dari diri sendiri dan juga oleh lingkungannya, menuju kesempurnaan manusiawinya.

Pendidikan memang berfungsi membantu peserta didik dalam pengembangan dirinya, yaitu pengembangan semua potensi dan kecakapan, serta karakteristik pribadinya ke arah yang positif, baik bagi dirinya maupun lingkungannya(Nana Syaodih Sukmadinata, 2004: 4).

Pendidikan juga berarti perpaduan sejumlah wawasan pengetahuan yang mampu membekali seseorang dengan beragam pengalaman (Ma,,mûn Shâlih Al-Nu“emân, 1998: 21). Atau sebagaimana yang dinyatakan Hasan Langgulung(2008: 1), pendidikan berarti pengembangan potensi-potensi yang terpendam dan tersembunyi. 
Kesimpulannya, dalam tataran konseptualistik-idealistik dapat dinyatakan bahwa pendidikan termasuk pendidikan Islam di dalamnya, adalah sebuah proses general yang multi dimensi, sistematis, dan kompleksitas serta seharusnya melibatkan berbagai pihak.

Sedangkan ketika term pendidikan dilabeli dengan term Islam, dalam realitas di Indonesia, walaupun banyak definisi yang dikemukakan para ahli mengenai pendidikan Islam, Muhaimin (2009: 14-15) menyimpulkan intinya ada dua yaitu:

Pertama, pendidikan Islam merupakan aktivitas pendidikan yang diselenggarakan atau didirikan dengan hasrat dan niat untuk mengejawantahkan ajaran dan nilai-nilai Islam. Sehingga dalam praktiknya, pendidikan Islam di Indonesia dapat dikelompokkan ke dalam lima jenis, yaitu:

1. Pondok Pesantren atau Madrasah Diniyah, yang menurut UU No. 20 Tahun 2003 tentang Sistem Pendidikan Nasional disebut sebagai pendidikan keagamaan (Islam) formal seperti Pondok Pesantren/Madrasah Diniyah (Ula, Wustha, 'Ulya, dan Ma'had'Ali).

2. Madrasah dan pendidikan lanjutannya seperti IAIN/STAIN atau Universitas Islam Negeri yang bernaung di bawah Departemen Agama.

3. Pendidikan usia dini/TK, sekolah/perguruan tinggi yang diselenggarakan oleh dan/atau berada di bawah naungan yayasan dan organisasi Islam.

4. Pelajaran agama Islam di sekolah/madrasah/perguruan tinggi sebagai suatu mata pelajaran atau mata kuliah, dan/atau sebagai program studi.

5. Pendidikan Islam dalam keluarga atau di tempat-tempat ibadah, dan/atau di forum-forum

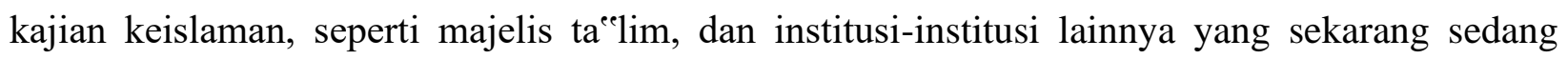
digalakkan oleh masyarakat, atau pendidikan (Islam) melalui jalur pendidikan non formal dan informal. 
Kedua, pendidikan Islam adalah sistem pendidikan yang dikembangkan dari dan disemangati atau dijiwai oleh ajaran dan nilai-nilai Islam. Dalam pengertian yang kedua ini, pendidikan Islam dapat mencakup:

1. Kepala sekolah/madrasah atau pimpinan perguruan tinggi yang mengelola dan mengembangkan aktivitas kependidikannya yang disemangati atau dijiwai oleh ajaran dan nilainilai Islam, serta tenaga-tenaga penunjang pendidikan (seperti pustakawan, laboran, teknisi sumber belajar,dan lain-lain) yang mendukung terciptanya suasana, iklim, dan budaya keagamaan Islam di sekolah/madrasah atau perguruan tinggi tersebut.

2. Komponen-komponen aktivitas pendidikan, seperti kurikulum atau program pendidikan, peserta didik yang tidak sekadar pasif-reseptif, tetapi aktif-kreatif, personifikasi pendidik/guru, konteks belajar atau lingkungan, alat/media/sumber belajar, metode, dan lain-lain yang disemangati atau dijiwai oleh ajaran dan nilai-nilai Islam, atau yang berciri khas Islam.

Dari kedua pengertian pendidikan Islam tersebut di atas, maka pengertian pertama lebih menekankan aspek kelembagaan dan program pendidikan Islam, dan yang kedua lebih menekankan aspek ruh dan spirit Islam yang melekat pada setiap aktivitas pendidikan (Muhaimin, 2009: 15).Demikianlah memang hakekat pendidikan Islam yang ada dan berlangsung dari waktu ke waktu, dari generasi ke generasi, dengan dinamika dan varian yang sedikit berbeda, setidaknya dalam konteks kedisinian dalam locus Indonesia.Adapun definisi manajemen

pendidikan Islam menurut para pakar di antaranya Ramayulis (2015: 372-373),adalah proses pemanfaatan semua sumber daya yang dimiliki (umat Islam, lembaga pendidikan, atau lainnya) baik perangkat keras maupun lunak.

Pemanfaatan tersebut dilakukan melalui kerjasama dengan orang lain secara efektif, efisien, dan produktif untuk mencapai kebahagiaan dan kesejahteraan baik di dunia maupun di akhirat.

\section{HASIL PEMBAHASAN}

\subsection{Isi Hasil dan Pembahasan}


Menurut pengakuannya dalam kata pengantar karyanya yang berjudul Manajemen Pendidikan Islam: Strategi Baru Pengelolaan Lembaga Pendidikan Islam (2007: v-vi), Mujamil Qomar menuturkan bahwa ia mulai

memberikan perhatian terhadap pencarian literatur manajemen pendidikan Islam hingga dengan penuh perjuangan dapat menyusun karyanya tersebut dikarenakan beberapa alasan mendasar.

Pertama, kepercayaan yang diberikan oleh Direktur Program Pascasarjana Universitas Islam Lamongan pada tahun 2000 untuk mengampu mata kuliah Manajemen Lembaga Pendidikan Islam.

Kedua, menguatnya perhatian terhadap manajemen pendidikan Islam di Indonesia yang dibuktikan dengan dimunculkannya Manajemen Pendidikan Islam sebagai mata kuliah, baik di jurusan dan/atau program studi pendidikan agama Islam maupun kependidikan Islam.

Ketiga, minim atau kurangnya literatur tentang manajemen pendidikan Islam.

Keempat, karya-karya yang telah ditulis tentang manajemen pendidikan Islam ternyata masih belum menyentuh substansi manajemen pendidikan Islam itu sendiri.

\subsubsection{Isi Hasil Pembahasan}

\section{Hakikat Manajemen Pendidikan}

Islam dan Impilkasinya Tanpa menjelaskan satu persatu susunan kata yang menyusunnya, Qomar (2007: 10) menjelaskan makna definitif dari manajemen pendidikan Islam sebagai proses pengelolaan lembaga pendidikan Islam secara Islami dengan cara menyiasati sumber-sumber belajar dan hal-hal lain yang terkait untuk mencapai tujuan pendidikan Islam secara efektif dan efisien.

Di bukunya yang lain, Strategi Pendidikan Islam (2013: 20), Qomar menegaskan bahwa manajemen pendidikan Islam yang dimaksudkan adalah manajemen pendidikan Islamyang ideal, 
yaitu manajemen pendidikan yang murni ditangkap dan dipahami dari pesan-pesan ajaran Islam, bukan manajemen pendidikan yang sudah terpengaruh oleh manajemen Barat, yang kini banyak diterapkan di lembaga-lembaga pendidikan Islam. Manajemen pendidikan Islam yang ideal adalah manajemen yang dirumuskan berdasarkan ajaran Islam yang tertuang di dalam Al-Qur"an dan Hadits.

Dari kedua definisi tersebut dapat dinyatakan bahwa dalam perspektif Qomar yang dimaksud dengan manajemen pendidikan Islam adalah manajemen yang harus dijiwai oleh ajaran Islam yang berlandaskan Al-Qur"an dan Hadits tanpa mengesampingkan fungsi utama dari manajemen sebagai kegiatan mengelola dan menyiasati pencapaian tujuan.

Lebih lanjut Qomar menjelaskan bahwa dari makna definitif manajemen pendidikan Islam tersebut memiliki implikasi (2007: 10-12) sebagai berikut:

Pertama, proses pengelolaan lembaga pendidikan Islam secara Islami; hal ini menghendaki adanya muatan-muatan nilai Islami misalnya penekanan pada penghargaan, maslahat, kualitas, kemajuan, dan pemberdayaan dengan berlandaskan pesan-pesan Al-Qur'ean dan Hadits.

Kedua, terhadap lembaga pendidikan Islam; bahwa objek dari secara khusus diarahkan untuk menangani lembaga pendidikan Islam dengan segala keunikannya, antara lain pesantren, madrasah, perguruan tinggi Islam, dan sebagainya.

Ketiga, proses pengelolaan lembaga pendidikan Islami menghendaki adanya

sikap inklusif dan eksklusif; hal ini menunjukkan sikap inklusif, yang berarti

kaidah-kaidah manajerial yang dirumuskan bisa dipakai untuk pengelolaan pendidikan selain pendidikan Islam selama ada kesesuaian sifat dan misinya.

Sedangkan yang dimaksud menunjukkan sifat eksklusif karena terfokus pada lembaga pendidikan Islam yang menjadi objek langsungnya. 
Keempat, dengan cara mensiasati; hal ini mengandung strategi yang menjadi salah satu pembeda antara administrasidengan manajemen.

Kelima, sumber-sumber belajar dan hal-hal lain yang terkait; hal ini memiliki cakupan yang cukup luas dan meliputi banyak hal.

Keenam, tujuan pendidikan Islam; hal ini merupakan arah dari seluruh kegiatan manajemen terutama yang berkaitan dengan pengelolaan lembaga pendidikan Islam.

Ketujuh, efektif dan efisien; maksudnya adalah berhasil guna dan berdaya guna.

Demikianlah pemikiran Qomar tentang hakikat manajemen pendidikan Islam dan implikasinya dalam pendidikan Islam itu sendiri.

\section{Objek Filosofis dan Praksis serta Dimensi dari Manajemen Pendidikan Islam}

Qomar (2007: 12-14) berpandangan bahwa ditinjau dari sistem filsafat, rumusan definitif manajemen pendidikan Islam sebagaimana tersebut di atas, telah mencakup sisi ontologi, epistemologi, dan aksiologi. Ontologi sebagai objek pengelolaan, berupa lembaga pendidikan Islam, sumber-sumber belajar, dan hal-hal lain yang terkait; epistemologi sebagai "cara atau metode" pengelolaan, berupa proses pengelolaan dan cara menyiasati; sedangkan aksiologi sebagai hasil pengelolaan berupa pencapaian tujuan pendidikan Islam. Adapun istilah efektif dan efisien merupakan keterangan yang menjelaskan aksiologi dan epietemologi. Efektif menekankan pada aksiologi, sedangkan efisien menitikberatkan pada epistemologi.

Kerangka filosofis dari manajemen pendidikan Islam tersebut dapat dipetakan dalam tabel berikut:

\begin{tabular}{|c|c|c|}
\hline $\begin{array}{c}\text { Subsistem } \\
\text { Filsafat }\end{array}$ & Komponen-komponen & Keterangan \\
\hline Ontologi & $\begin{array}{l}\text { - Lembaga pendidikan Islam } \\
\text { - Sumber-sumber belajar }\end{array}$ & $\begin{array}{l}\text { - Objek pengelolaan makro } \\
\text { - Objek pengelolaan meso }\end{array}$ \\
\hline
\end{tabular}




\begin{tabular}{|l|ll|ll|}
\hline & $\bullet$ & Hal-hal lain yang terkait & $\bullet$ & Objek pengelolaan mikro \\
\hline Epistemologi & $\bullet$ & Proses pengelolaan secara Islami & $\bullet$ & Cara pengelolaan makro \\
& $\bullet$ & Cara menyiasati & $\bullet$ & Cara pengelolaan mikro \\
\hline Aksiologi & $\bullet$ & Pencapaian tujuan pendidikan Islam & $\bullet$ & Hasil pengelolaan \\
\hline Gabungan & $\bullet$ & Efektif dan efisien & $\bullet$ & Menjelaskan keadaan aksiologi \\
Aksiologi & & & dan epitemologi $:$ efektif \\
dan & & & menekankan pada hasil \\
Epistemologi & & & (aksiologi), sedang efisien \\
& & & menekankan pada cara \\
& & (epistemologi) & \\
\hline
\end{tabular}

Di samping itu, Qomar (2007:15) juga menyatakan bahwa manajemen pendidikan Islam memiliki objek bahasan yang cukup kompleks yang dijadikan bahan untuk kemudian diintegrasikan untuk mewujudkan manajemen pendidikan Islam yang berciri khas Islami. Kata "Islam", menurutnya menjadi identitas manajemen pendidikan Islam dimaknai sebagai Islam wahyu yang meliputi Al-Qurean dan Hadits atau Islam budaya yang meliputi ungkapan sahabat Nabi Muhammad S.A.W., pemahaman cendekiawan Muslim, dan budaya umat Islam.

Oleh karena itu (2007: 16), objektifitas manajemen pendidikan Islam secara praksis juga meliputi:

a. Teks-teks wahyu, baik Al-Qurean maupun Hadits yang terkait dengan manajemen pendidikan Islam.

b. Perkataan-perkataan (aqwâl) para sahabat Nabi maupun ulama dan cendekiawan Muslim yang terkait dengan manajemen pendidikan.

c. Realitas perkembangan lembaga pendidikan Islam.

d. Kultur komunitas (pimpinan dan pegawai) lembaga pendidikan Islam. 
e. Ketentuan kaidah-kaidah manajemen pendidikan.

Bahan a sampai d menurut Qomar (2007: 16) merefleksikan ciri khas Islam pada bangunan manajemen pendidikan Islam, sedangkan bahan e merupakan tambahan yang bersifat umum dan karenanya dapat digunakan untuk membantu merumuskan bangunan manajemen pendidikan Islam. Tentunya setelah diseleksi berdasarkan nilai-nilai Islam dan realitas yang dihadapi oleh lembaga pendidikan Islam. Nilai-nilai Islam tersebut merupakan refleksi wahyu, sedangkan realitas tersebut sebagai refleksi budaya atau kultur.

Dengan demikian dapat disimpulkan bahwa objektifitas manajemen pendidikan Islam dalam perspektif Qomar meliputi objek filosofis berkaitan dengan aspek ontologi, epistemologi, dan aksiologi serta meliputi objek idealitas berupa wahyu dan objek realitas berupa kultur atau budaya kaum Muslimin.

Di sisi lain berdasarkan pengalaman di lapangan tentang perkembangan pendidikan Islam di Indonesia yang sangat bervariasi dan secara kuantitatif banyak jumlahnya, dalam buku Dimensi Manajemen Pendidikan Islam Qomar (2016) mendeteksi bahwa objek pembahasan manajemen pendidikan Islam memiliki banyak dimensi. Baik yang bersifat informal, nonformal, maupun formal sebagai sebuah pohon dengan cakupan dimensinya masing-masing yang dapat diibaratkan sebagai batang, cabang, ranting, dan sub-sub ranting.

Secara garis besar, dimensi manajemen pendidikan Islam tersebut dapat dipetakan dalam tabel berikut: 


\section{MANAGEMENT OF EDUCATION Jurnal Manajemen Pendidikan Islam}

Fakultas Tarbiyah dan Keguruan UIN Antasari Banjarmasin

\begin{tabular}{|c|c|}
\hline Batang Dimensi & Cabang Dimensi \\
\hline $\begin{array}{l}\text { Manajemen Pendidikan } \\
\text { Agama dalam Keluarga }\end{array}$ & $\begin{array}{l}\text { a. Manajemen Pendidikan Agama pada Anak } \\
\text { b. Manajemen Pendidikan Agama dalam Keluarga Karir } \\
\text { c. Manajemen Pendidikan Agama dalam Keluarga Broken } \\
\text { Home } \\
\text { d. Manajemen Pendidikan Agama pada Remaja } \\
\text { e. Manajemen Pendidikan Agama pada Remaja } \\
\text { f. Mangangguran } \\
\text { g. Manajemen Pendidikan Agama pada Suami-Istri } \\
\text { h. Manajemen Pendidikan Agama pada Orang Tua } \\
\text { i. Manajemen Pendidikan Agama pada Pembantu Rumah } \\
\end{array}$ \\
\hline $\begin{array}{l}\text { Manajemen Pengajian } \\
\text { dalam Masyarakat }\end{array}$ & $\begin{array}{l}\text { a. Manajemen Pengajian di Rumah Ustadz/Kiai } \\
\text { b. Manajemen Pengajian di Langgar/Surau/Masjid } \\
\text { c. Manajemen Pengajian dalam Kelompok Tahlilan } \\
\text { d. Manajemen Pengajian dalam Kuliah Tujuh Menit } \\
\text { e. Manajemen Pengajian Majelis Taklim } \\
\text { f. Manajemen Pengajian dalam Kursus Privat } \\
\text { g. Manajemen Pengajian Umum } \\
\text { h. Manajemen Khotbah Jum }{ }^{\text {eeat }} \\
\text { i. Manajemen Pengajian dalam Hajatan Keluarga } \\
\text { j. Manajemen Pembinaan Kepribadian Muslim Melalui }\end{array}$ \\
\hline $\begin{array}{l}\text { Manajemen Pendidikan } \\
\text { Pesantren }\end{array}$ & Manajemen Pendidikan Pesantren Anak-anak \\
\hline
\end{tabular}




\section{MANAGEMENT OF EDUCATION Jurnal Manajemen Pendidikan Islaim}

Fakultas Tarbiyah dan Keguruan UIN Antasari Banjarmasin

\begin{tabular}{|c|c|}
\hline & $\begin{array}{ll}\text { b. } & \text { Manajemen Pendidikan Pesantren Siswa } \\
\text { c. } & \text { Manajemen Pendidikan Pesantren Mahasiswa (PESMA) } \\
\text { d. } & \text { Manajemen Pendidikan Pesantren Kampus } \\
\text { e. } & \text { Manajemen Pendidikan Pesantren Machad Ali } \\
\text { f. } & \text { Manajemen Pendidikan Pesantren Takhassus } \\
\text { g. } & \text { Manajemen Pendidikan Pesantren Al-Qur"an } \\
\text { h. } & \text { Manajemen Pendidikan Pesantren Bahasa } \\
\text { i. } & \text { Manajemen Pendidikan Pesantren Keterampilan . } \\
\text { j. } & \text { Manajemen Pendidikan Pesantren Kilat } \\
\text { k. } & \text { Manajemen Pendidikan Pesantren Ramadhan } \\
\text { 1. } & \text { Manajemen Pendidikan Pesantren Rehabilitasi } \\
\text { m. } & \text { Manajemen Pendidikan Pesantren Buruh } \\
\text { n. } & \text { Manajemen Pendidikan Pesantren Virtual }\end{array}$ \\
\hline $\begin{array}{l}\text { Manajemen Pendidikan } \\
\text { Madrasah }\end{array}$ & $\begin{array}{l}\text { a. Manajemen Pendidikan Madrasah Diniyah } \\
\text { b. Manajemen Pendidikan Madrasah Diniyah Takmiliyah } \\
\text { c. Manajemen Pendidikan Madrasah Al-Qur"an } \\
\text { d. Manajemen Pendidikan Madrasah Aliyah Program } \\
\text { Keterampilan (MAPK) } \\
\text { e. Manajemen Pendidikan Madrasah Aliyah Kejuruan } \\
\text { (MAK) } \\
\text { f. Manajemen Pendidikan Madrasah Terpadu } \\
\text { g. Manajemen Pendidikan Madrasah Unggulan/Model }\end{array}$ \\
\hline $\begin{array}{l}\text { Manajemen Pendidikan } \\
\text { Agama Islam di PAUD, }\end{array}$ & $\begin{array}{l}\text { a. Manajemen Pendidikan Agama Islam di Taman Penitipan } \\
\text { Anak/Kelompok Bermain }\end{array}$ \\
\hline
\end{tabular}




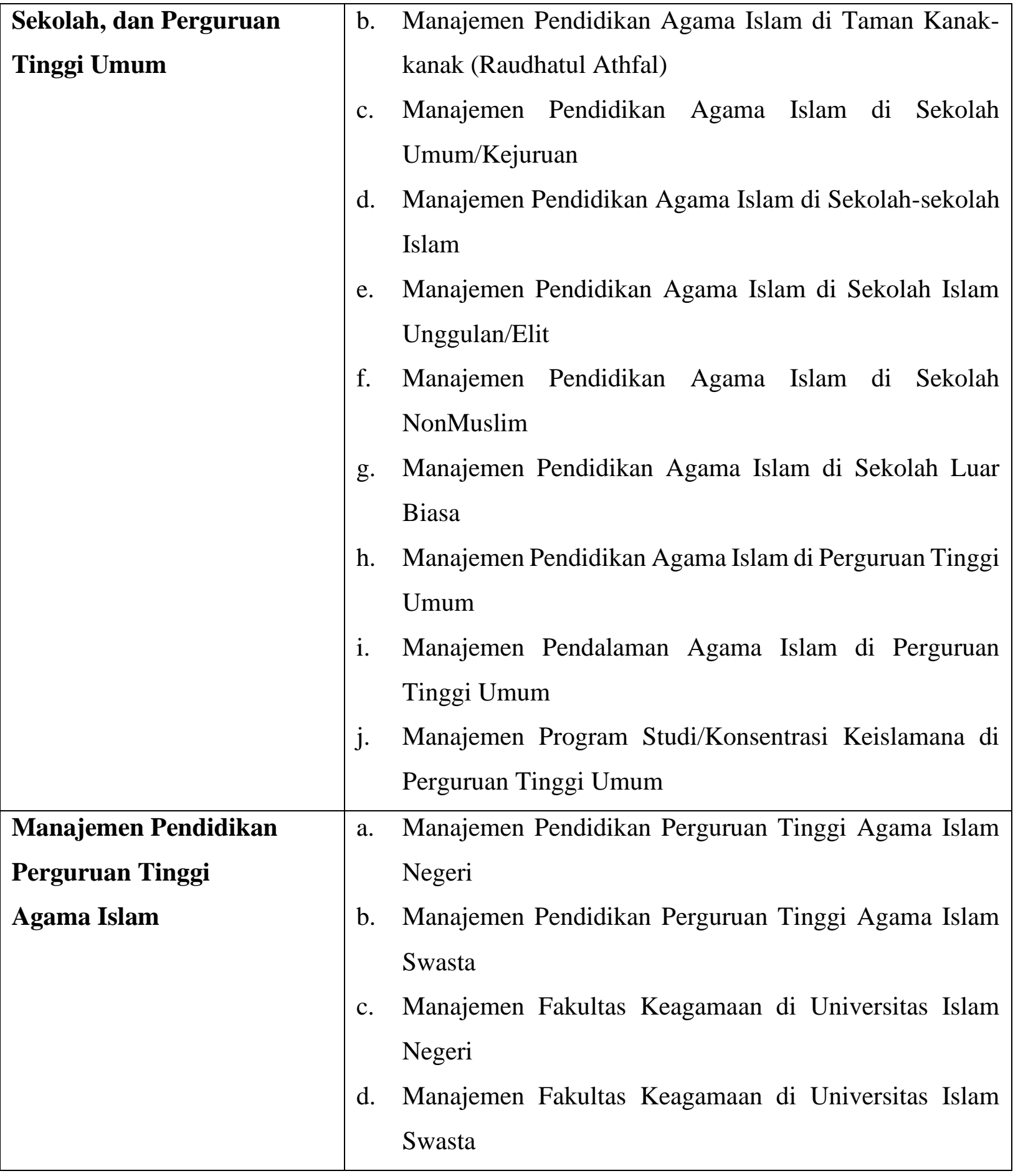




\begin{tabular}{|c|c|}
\hline & $\begin{array}{l}\text { e. Manajemen Pengkajian Islam pada Jurusan/Program } \\
\text { Studi Umum di Perguruan Tinggi Agama Islam Negeri } \\
\text { f. Manajemen Pengkajian Islam pada Jurusan/Program } \\
\text { Studi Umum di Universitas Islam Swasta }\end{array}$ \\
\hline $\begin{array}{l}\text { Manajemen Pembinaan } \\
\text { Agama Islam di } \\
\text { Lembaga-lembaga } \\
\text { Nonpendidikan }\end{array}$ & $\begin{array}{l}\text { a. Manajemen Pembinaan Agama Islam di Panti Sosial } \\
\text { b. Manajemen Pembinaan Agama Islam di Panti Asuhan } \\
\text { Yatim-Piatu } \\
\text { c. Manajemen Pembinaan Agama Islam di Penampungan } \\
\text { Tenaga Kerja } \\
\text { d. Manajemen Pembinaan Agama Islam di Perkantoran } \\
\text { e. Manajemen Pembinaan Agama Islam di Kemiliteran } \\
\text { f. Manajemen Pembinaan Agama Islam di Perusahaan } \\
\text { g. Manajemen Pembinaan Agama Islam di Rumah Sakit } \\
\text { h. Manajemen Pembinaan Agama Islam di Lembaga } \\
\text { i. Manajemen Pembinaan Agama Islam di Kompleks } \\
\text { j. Manajemen Pendidikan Pesantren Waria }\end{array}$ \\
\hline
\end{tabular}

Dimensi manajemen pendidikan seperti yang telah dipetakan Qomar sebagaimana tersebut di atas, bisa saja belum mencakup semua dimensi manajemen yang telah terjadi dan akan terus berkembang dalam realitas lembaga pendidikan Islam, baik informal, nonformal, maupun formal.

\section{Ciri dan Karakteristik Manajemen Pendidikan Islam}

Qomar menegaskan bahwa kata "Islam" pada "manajemen pendidikan" secara tidak langsung menuntut tanggung jawab intelektual untuk menjelaskan ciri-ciri manajemen pendidikan Islam sebagai identitas pembeda dengan jenis manajemen pendidikan lainnya (2013: 20). 
Oleh karena itu, ciri dan karakteristik dari manajemen pendidikan Islam yang cukup panjanglebar dikemukakan Qomar (2013: 20-26) dapat diringkas sebagai berikut:

Pertama, berdasarkan pada wahyu (Al-Qur"an dan Hadits) sehingga nilai-nilai Islam mewarnai seluruh komponen maupun kegiatan manajemen pendidikan Islam.

Kedua, bangunan manajemen pendidikan Islam diletakkan di atas empat sandaran, yaitu sandaran teologis, rasional, empiris, dan teoritis.

Sandaran teologis berupa teks-teks wahyu, baik Al-Qur"an maupun Hadits yang terkait dengan manajemen pendidikan.

Sandaran rasional berupa pendapat-pendapat atau perkataan-perkataan (aqwâl) para sahabat Nabi, tabiin, mujtahid, mujadid, ulama, maupun cendekiawan Muslim yang terkait dengan manajemen pendidikan.

Sandaran empiris yaitu berupa realitas perkembangan lembaga pendidikan Islam dan kultur komunitas (pimpinan dan pegawai) lembaga pendidikan Islam.

Sedangkan sandaran teoritis berupa ketentuan kaidah manajemen pendidikan yang telah diseleksi berdasarkan nilai-nilai Islam dan realitas yang dihadapi oleh lembaga pendidikan Islam.

Ketiga, manajemen pendidikan Islam bercorak theoantroposentris (berpusat pada Tuhan dan manusia) yang memiliki orientasi yang seimbang antara hablu min Allah (orientasi kepada Tuhan) dan hablu min an-nas(orientasi kepada manusia) sebagai konsekuensi penerapan sandaran teologis, rasional, empiris, dan teoritis.

Keempat, manajemen pendidikan Islam mengembangkan misi emansipatoris dalam membebaskan semua pelaku pendidikan Islam dari keterpasungan guna merintis dan membangun kehidupan masa depan yang lebih berperadaban dan berkebudayaan tinggi untuk meraih kesejahteraan hidup bagi manusia. 
Kelima, praktek manajemen pendidikan Islam dilakukan melalui mekanisme transformatif dengan memusatkan konsentrasi kegiatannya pada upaya mentransformasikan dari keadaan, kondisi, kecenderungan, tradisi, budaya, pandangan, mindset, pola sikap, pola hidup, pola bergaul, pola interaksi, pola kepemimpinan, pola kerja, dan pola belajar yang serba negatif, destruktif, dan kontraproduktif berubah menjadi positif, konstruktif, dan produktif.

Keenam, manajemen pendidikan Islam mengutamakan proses pembentukan kepribadian Muslim berupa terbentuknya kualitas kepribadian Muslim yang utama yang diharapkan benarbenar terbukti dan teruji di tengah-tengah masyarakat.

Ketujuh, keberhasilan atau kemajuan yang ingin diraih oleh manajemen pendidikan Islam adalah integrasi kematangan kematangan spiritual (iman), intelektual, amal, ketrampilan, dan akhlak yang merefleksikan dan menampilkan kepribadian Muslim yang utuh.

Inilah tujuh ciri dan karakteristik manajemen pendidikan Islam yang berhasil dideskripsikan oleh Qomar secara bernas.

\section{Perbedaan Antara Manajemen Pendidikan Islam dan Manajemen Pendidikan}

Setelah mendeskripsikan hakikat, objektifitas, dan ciri/karakteristik manajemen pendidikan Islam, Qomar (2013: 27-31) menyatakan bahwa secara sekilas terdapat beberapa kesamaan antara manajemen pendidikan Islam dengan manajemen pendidikan. Namun bila diperhatikan secara cermat antara keduanya, terdapat beberapa perbedaan ringkas sebagai berikut:

a. Dasar utama manajemen pendidikan Islam berupa wahyu, sedangkan dasar utama manajemen pendidikan berupa aliran filsafat naturalisme. Ringkasnya, bila filsafat telah melahirkan ilmu, maka wahyu telah melahirkan filsafat dan ilmu sekaligus.

b. Sandaran manajemen pendidikan Islam meliputi sandaran teologis, sandaran rasional, sandaran empiris, dan sandaran teoritis. Sedangkan sandaran manajemen pendidikan hanya dua, yaitu sandaran rasional dan sandaran empiris. 
c. Manajemen pendidikan Islam bercorak theoantroposentris yang seimbang, sedangkan manajemen pendidikan bercorak antroposentris (berpusat pada manusia semata).

d. Manajemen pendidikan Islam mengembangkan misi emansipatoris, sedangkan manajemen pendidikan mengembangkan misi kapitalisme yang menyebabkan komersialisasi pendidikan.

e. Mekanisme yang ditempuh manajemen pendidikan Islam adalah mekanisme transformatif, sedangkan mekanisme dalam manajemen pendidikan mekanisme transfer yang lebih cenderung untuk menekankan pada input yang pandai untuk menghasilkan output yang pandai juga.

f. Manajemen pendidikan Islam menekankan pada kemampuan memproses yang mengandalkan tahap tengah antara lain dalam upaya atau rekayasa. Sedangkan manajemen pendidikan menekankan pada kemampuan menampung modal (kualitas yang baik pada input) pada tahap awal antara lain dengan mengandalkan rata-rata nilai yang baik sejak permulaannya.

g. Tujuan yang ingin diraih oleh manajemen pendidikan Islam adalah keberhasilan mengintegrasikan kematangan dan keunggulan spiritual (iman), intelektual, amal, keterampilan, dan akhlak. Sedangkan tujuan yang ingin dicapai oleh manajemen pendidikan hanyalah keunggulan pengetahuan, sikap, dan keterampilan yang sangat dipengaruhi oleh Taksonomi Bloom.

Ketujuh perbedaan yang telah dikemukakan Qomar tersebut, menurutnya jika ditelaah lebih mendalam, kemungkinan masih banyak perbedaan lain dari keduanya.

\section{Eksistensi dan Hambatan Manajemen Pendidikan Islam}

Berdasarkan penuturan Qomar terutama ketika berinteraksi dengan pelbagai kalangan dalam kerangka pembelajaran, ia sering mendapatkan pertanyaan yang cukup menggelitik, yaitu apakah manajemen pendidikan itu ada?

Qomar kemudian menyatakan bahwa eksistensi atau keberadaan manajemen pendidikan Islam itu nyata adanya dimana setidaknya dapat ditinjau dari tiga sudut pandang (2013: 13-14). 
Pertama, dari segi pengalaman atau penerapan, bahwa manajemen pendidikan Islam telah dipraktikkan oleh Rasulullah S.A.W. secara lebih makro, lebih rumit, dan lebih kompleks dalam mengelola pendidikan masyarakat.

Kedua, dari segi konsep normatif teologis, bahwa banyak ayat Al-Qurean dan teks Hadits yang memberi inspirasi terhadap manajemen pendidikan Islam, baik secara redaksional maupun substansif.

Ketiga, dari segi bangunan terori, bahwa manajemen pendidikan Islam merupakan embrio bangunan ilmu yang berdiri sendiri yang hingga sekarang belum dianggap mapan secara teoritis sehingga membutuhkan keterlibatan para pakar pendidikan Islam dalam memberikan kontribusi teori untuk memperkokoh konstruksi ilmu manajemen pendidikan Islam.

Namun dalam penerapan dan pengelolaannya di lembaga pendidikan Islam, Qomar menyebutkan (2007: 17 28) ada beberapa hambatan dalam implementasi manajemen pendidikan Islam, yaitu;

Pertama, ideologi, politik, dan tekanan (pressure) kelompok-kelompok yang berkepentingan.

Dalam lembaga-lembaga pendidikan Islam terutama yang berstatus negeri, sering kali terjadi pertentangan ideologi antar organisasi sosial keagamaan utamanya, misalnya Muhammadiyah dan NU, atau antar organisasi kemahasiswaan seperti HMI dengan PMII dan sebagainya. Nuansa politik yang terjadi di lingkungan pendidikan, baik di kalangan dosen (guru, pendidik), mahasiswa (siswa, peserta didik), bahkan karyawan yang sangat dominan, mengalahkan nuansa akademik yang harusnya mengarah kepada pemberdayaan intelektual bukan pada gerakan-gerakan politik. Lantaran pertentangan- pertentangan ini, akhirnya politik kepentingan memasuki arena lembaga pendidikan dengan memberikan tekanan-tekanan tertentu.

Dengan demikian, menguatnya ideologi dari organisasi menyebabkan kecenderungan ini memasuki wilayah pendidikan. Hasilnya, proses pendidikan yang semestinya diniatkan untuk 
membangun sumber daya manusia yang pandai, berakhlak dan terampil bergeser karena mereka dibentuk menjadi orang-orang yang militan dan fanatik mengikuti organisasi sosial-keagamaan.

Kedua, kondisi sosio-ekonomik masyarakat dan animo-finansial lembaga.

Masyarakat lembaga pendidikan Islam di Indonesia secara sosio ekonomik rata-rata berada dalam kategori kelas menengah ke bawah. Ekonomi orang tua siswa lemah, ekonomi karyawan, pengajar bahkan pemimpinnya juga berekonomi lemah. Ini merupakan kendala serius bagi lembaga pendidikan Islam untuk memecu kemajuan yang signifikan. Bagaimana seorang kepala madrasah ataupun pengajar lembaga-lembaga pendidikan Islam dituntut untuk mengelola, melakukan inovasi strategi, pendekatan, methode dan desian pembelajaran dengan baik sementara ekonomi keluarganya amburadul ataupun sampai kebutuahan dasar sehari-harinya saja tidak terpenuhi?

Ketiga , kompetisi status kelembagaan dan diskriminasi kebijakan pemerintah.

Mayoritas lembaga pendidikan Islam berstatus swasta dananya bersumber dari usaha swadaya masyarakat (wali murid) yang kondisi ekonominya tergolong level menengah ke bawah. Minimnya keuangan lembaga pendidikan Islam menyebabakan posisi lembaga pendidikan tersebut selalu terbelakang dan sulit maju. Sebab, semuapeningkatan komponen lembaga pendidikan membutuhkan biaya yang tidak sedikit dan pembiayaan ini menentukan apakah lembaga pendidikan ini segera bisa ditingkatkan atau dibiarkan dalam kondisi yang memprihatinkan. Dalam waktu yang bersamaan, kebijakan pemerintah tidak pernah berpihak kepada lembaga pendidikan Islam swasta. Kepedulian dan keberpihakan pemerintah hanya banyak terarah pada lembaga pendidikan negeri sehingga beban lembaga pendidikan Islam swasta semakin berat.

Keempat, keadaan potensi intelektual siswa/mahasiswa.

Rata-rata siswa/mahasiswa yang mendaftar di berbagai lembaga pendidikan Islam adalah mereka yang merasa tidak mungkin diterima di lembaga pendidikan umum yang maju dan 
terutama berstatus negeri karena menyadari kemampuannya yang rendah, sehingga tidak pernah mendaftar sama sekali. Sebagian dari meraka adalah yang telah gagal masuk ke lembaga pendidikan umum negeri kemudian memilih lembaga pendidikan Islam. Keadaan ini menunjukkan adanya unsur keterpaksaan. Kalaulah bukan keterpaksaan, setidaknya lembaga pendidikan Islam tetap bukan pilihan utama bagi siswa/mahasiswa. Kondisi psikologis ini tentunya tidak dapat memberikan pengaruh positif untuk membangkitkan gairah belajar belajar guna mengejar pengusaan pengetahuan, baik yang difasilitasi lembaga atau inisiatif sendiri.

Pada bagian yang lain, lembaga pendidikan Islam tidak mampu melakukan seleksi penerimaan peserta didik baru secara ketat dan kompetitif. Biasanya selisih antara kuota yang direncanakan dengan jumlah siswa/mahasiswa yang mendaftar tak berbeda jauh, bahkan tak jarang peserta didik yang mendaftar lebih sedikit dari pada kuota yang direncanakan. Jadi, sulit untuk melakukan seleksi. Keadaan ini membuat dilema bagi pemimpin lembaga pendidikan Islam. Jika tak ada seleksi, maka peserta didik yang diterima bisa jadi berasal dari kalangan yang rendah secara intelektual. Akan tetapi, jika diseleksi secara ketat hanya akan diperoleh siswa/mahasiswa yang amat sedikit, yang akan menimbulkan masalah untuk meningkatkan potensi keuangan lembaga.

Kelima, keberadaan motif dakwah pada pendirian lembaga pendidikan Islam.

Motif dakwah dalam pendirian lembaga pendidikan Islam membawa dampak positif dan negatif. Dampak positifnya adalah memiliki kekuatan untuk survive meskipun jumlah siswa/mahasiswanya hanya sedikit. Sementara itu, segi negatifnya terkadang menimbulkan kondisi serba tidak teratur, tidak terencana dengan matang, serba tidak kompetitif, dan serba mengalami kemunduran. Dengan adanya motif dakwah, timbulah konsekuensi-konsekuensi yang menjadi akibat. Misalnya, lembaga didirikan secara asal-asalan tanpa melalui perencanaan yang matang untuk memenuhi berbagai komponen pendukungnya. Layaknya gerakan dakwah yang berangkat dari bawah, dengan menggunakan pendekatan pahala dan konsep lillahi ta'ala sehingga terkadang mengabaikan kesejahteraan pegawai dan menerima semua pendaftar tanpa seleksi. 


\section{KESIMPULAN}

Manajemen pendidikan Islam sebagaimana dinyatakan secara gamblang oleh Prof. Dr. Mujamil Qomar, M.Ag., merupakan salah satu faktor keberhasilan pendidikan Islam, baik secara teoritiskonseptual maupun dalam tataran realitas-ekspektasional dimana seharusnya mendapatkan atensi perhatian yang tinggi.

Banyak pemikiran Qomar yang menarik tentang manajemen pendidikan Islam. Di antara yang patut mendapatkan apresiasi dan telaah mendalam adalah tentang hakikat manajemen pendidikan Islam dan impilkasinya, objek filosofis dan praksis serta dimensi dari manajemen pendidikan Islam, ciri dan karakteristik manajemen pendidikan Islam, perbedaan antara manajemen pendidikan Islam dan manajemen pendidikan, serta tentang eksistensi dan hambatan manajemen pendidikan Islam.

\section{DAFTAR PUSTAKA}

Abdul Jawwad, M. (2004). Menjadi Manajer Sukses. Jakarta: Gema Insani. Yogyakarta.

Badaruddin, K. (2009). Filsafat Pendidikan Islam: Analisis Pemikiran Prof. Dr. Syed Muhammad Al-Naquib Al-Attas. Yogyakarta: Pustaka Pelajar.

Departemen Pendidikan Nasional. (2012). Kamus Besar Bahasa Indonesia Pusat Bahasa: Edisi Keempat. Jakarta: PT Gramedia Pustaka Utama.

Hassân, H. Muhammad. (1414 H.). Wasâ 'il Muqâwamah Al-Ghazw AlFikrî li Al-'Âlam al-Islâmî. Mekkah:Mathâbiee Râbithah Al-"êllam AlIslâmî.

Jalaluddin dan Said, U. (1999). Filsafat Pendidikan Islam: Konsep dan Perkembangan. Jakarta: PT. RajaGrafindo Persada.

Khirrî̀î, M. "Abd Al-“Azîz Al-. (1420 H.). Al-Ghazw Al-Fikrî li Al-Ummah Allslâmiyyah: Mâdhîhi wa Hâdhiruhu. Riyadh: Dâr Al-Shamaiê̂̂. 
Kîlânî, M. "Irsân Al-. (1987). Falsafah AlTarbiyah Al-Islâmiyyah: Dirâsah Muqâranah baina Falsafah AlTarbiyah Al-Islâmiyyah wa Al-Falsafât Al-Tarbawiyyah Al-Mu'âshirah. Mekkah: Maktabah Al-Manârah.

Langgulung, H. (2008). Asas-Asas Pendidikan Islam,. Jakarta: Pustaka Al-Husna Baru.

Machali, I. dan Hidayat, A. (2018). The Hand Book of Education Management: Teori dan Praktik Pengelolaan Sekolah/Madrasah di Indonesia. Jakarta: PrenadaMedia Group.

Mastuhu. (2003). Menata Ulang Sistem Pendidikan Nasional dalam Abad 21. Jakarta: Safiria Insania Press.

Misdar, M. (2017). Sejarah Pendidikan dalam Islam. Jakarta: PT RajaGrafindo Persada.

Muhaimin. (2009). Rekonstruksi Pendidikan Islam: Dari Paradigma Pengembangan, Manajemen Kelembagaan, Kurikulum Hingga Strategi Pembelajaran. Jakarta: PT RajaGrafindo Persada.

Nata, A. (2016). Sosiologi Pendidikan Islam. Jakarta: PT RajaGrafindo

Persada.

Nuemân, M. Shâlih Al-. (1998). Mabâdi' Tarbawiyyah fî Âyât A-Nidâ ' li Alladzîna Âmanû: Dirâsah Tahlîliyyah. Beirut: Dâr Al-Kutub AlTsaqâfiyyah.

Qomar, M. (2006). Epistemologi Pendidikan Islam dari Metode Rasional hingga Metode Kritik. Jakarta: Penerbit Erlangga.

Qomar, M. (2007). Manajemen Pendidikan Islam Strategi baru Pengelolaan Lembaga Pendidikan Islam. Jakarta: Penerbit Erlangga.

Qomar, M. (2012). Kesadaran Pendidikan: Suatu Penentu Keberhailan Pendidikan. Yogyakarta: Ar-Ruzz Media. 
Qomar, M. (2012). Merintis Kejayaan Islam Kedua: Merombak Pemikiran dan Mengembangkan Aksi. Yogyakarta: Teras.

Qomar, M. (2013). Strategi Pendidikan Islam. Jakarta: Penerbit Erlangga.

Qomar, M. (2014). Menggagas Pendidikan Islam. Bandung: PT Remaja Rosdakarya.

Qomar, M. (2016). Dimensi Manajemen Pendidikan Islam. Jakarta: Penerbit Erlangga.

Ramayulis. (2015). Ilmu Pendidikan Islam. Jakarta: Kalam Mulia.

Sanaky, H. AH. (2003). Paradigma Pendidikan Islam Membangun Masyarakat Madani Indonesia. Yogyakarta: Safiria Insania Press dan Magister Studi Islam Universitas Islam Indonesia.

Sukmadinata, N. Syaodih. (2004). Landasan Psikologis Proses Pendidikan, Bandung: PT Remaja Rosdakarya. Sulistyorini. (2009). Manajemen Pendidikan Islam: Konsep, Strategi, dan Aplikasi. Yogyakarta: TerasLandasan Psikologis Proses Pendidikan, Bandung: PT Remaja Rosdakarya.

Sulistyorini. (2009). Manajemen Pendidikan Islam: Konsep, Strategi, dan Aplikasi. Yogyakarta: Teras 